\title{
THE PREPARATION OF POLISH SOCIAL WORKERS TO WORK WITH PERSON EXPERIENCING DOMESTIC VIOLENCE. EDUCATIONAL EXPERIENCES AND CHALLENGES
}

\author{
Joanna Malgorzata Lukasik \\ Jesuit University Ignatianum in Cracow, Poland \\ Norbert Gerard Pikuła \\ Pedagogical University of Cracow, Poland \\ Katarzyna Agata Jagielska \\ Pedagogical University of Cracow, Poland
}

\begin{abstract}
Today's social worker has to face many new challenges that arise due to socioeconomic and cultural changes. One of the extremely important and difficult areas of social workers' job is to work with people who are experiencing domestic violence. The aim of the following article is to show previous experience in the field of theoretical and practical social worker's training in work with people experiencing domestic violence and the difficulties arising because of the imperfections of the system (i.e. due to lack of appropriate diagnostic tools, intervention strategies and supporting institutions). To show the weaknesses of education, a secondary analysis of the data (including programs, study plans) was made and expert interviews with employees who undertake work with a person experiencing violence were conducted. The analysis allowed to propose a concept of social workers' training in working with a person experiencing domestic violence (child, woman, elderly person), based on best practices, i.e. from Israel and Canada
\end{abstract}

Keywords: education of social workers; work with victims of violence; domestic violence; new training programs.

\section{Introduction}

Aging of the society carries a lot of socio-economic consequences while being a big challenge for the social policy of the state. Looking at the changing demographic situation from the long run perspective one can claim that at some moment there will be a situation when the number of the elderly surmounts the number of the young considerably which will cause imbalance of the generation ratio drastically.

The subject of social workers' education for the work with seniors is important due to a few reasons. One of them is the increase of the demand for 
caring services connected to the increase of the number of elderly people and their prolonging lifespan. Another reason is the changes of family life and lack of interest for the elderly among their family. A further reason is created by phenomena marginalized by family members and social and medical workers like abuse against seniors and ageism which shows itself by, among other, aversion towards the elderly and accordingly the young do not connect their future with their work with the elderly. In Polish conditions the current situation in social aid plays an important part as well.

Educating social workers for work with the elderly is a big challenge. In the times set for the cult of the youth it is hard to persuade young people that seniors may be and are active, have their desires and are able to realize them and that working with the elderly is not degradation but it is equally important and satisfying as any other job. Educating young people towards caring for an elderly person is not popular.

The proof for the need of educating social workers towards work with seniors is the fact that in Poland the state or the art of social work services for seniors is unsatisfactory and usually comes down to caring services (72\%) and financial help ( $52 \%)$. Social work is indicated only by each fourth of the surveyed while clubs for seniors and specialistic guidance exist only in one tenth of the surveyed. (Krzyszkowski, 2013, 13). Similarly, apart from the interest in social work with the elderly itself, the quality of education taking into consideration the ability of diagnosing various needs and situations experienced by seniors in both their family and institution environment.

Therefore, the aim of this article is to highlight the importance of knowledge and skills of students of social work in the field of diagnosis, intervention and support of older people experiencing violence. Previous studies carried out among social workers in the field of counteracting of violence against the elderly (Tobiasz-Adamczyk, 2009) and analysis of the plans and programs of social workers training allow to draw conclusions that education in this area is marginal.

\section{The phenomenon of elder abuse and the knowledge of social workers}

Elder abuse (see Krug et al., 2002; Lachs \& Pillemer, 2004) is a single or a repetitive intentional action or non-action carrying the risk of hurting the elderly person who is under care of the guardian being in such a relation to that person which should ensure well-being, while, in reality it is a source of "harm or stress for the senior" (The Toronto Declaration on the Elder Abuse, 2002).

In the light of gerontological literature elderly abuse is most often connected to family violence (Freeman, 2008; Hwalek \& Sengstock, 1986; Johnson, 1986), or there are various forms of it stressed in the analysis, e.g. physical abuse, neglect, mental, sexual, material abuse, breaking the rights, financial abuse or 
their consequences like: emotional or physical harm (Rathbone-McCuan, 1980; Chen, 1981; Gioglio, Sengstock, \& Hwalek, 1986). The analysis of the chosen definitions of the phenomenon of abuse (e.g. Nerenberg, 2006) allows to identify two important dimensions of the abuse connected to the role of the abuser and the nature of the activity (aggressive and invasive action towards the elderly person vs forsaking the action on the side of the guardian and/or neglecting the duties towards the elder) (see Johnson, 1986). It is worth underlining that the dimension concerning the nature of activity does not include the phenomenon of self-neglect, the basis of which is self directed aggression. The mentioned phenomenon is currently a subject of intense research (Band-Winterstein \& Eisikovits, 2014; Band-Winterstein et al., 2014; Band-Winterstein et al., 2006; Band-Winterstein, 2015a, 2015b ${ }^{1}$ ).

The typology suggested by World Health Organization (WHO) (Krug et al., 2002) defines forms of self aggression, e.g. self neglect, and those imposed by activity of other people, groups or institutions, eg. social marginalization, ageism which are harmful from the point of view of the elderly. There are a lot of theories claimed as representative for the way of thinking of the reasons and mechanisms of abuse (James \& Gilliland, 2013). The factors defined in them may interact in more or less complicated ways. Among them the most important are (James \& Gilliland, 2013; Tobiasz-Adamczyk, 2009; Freeman, 2008; Hwalek \& Sengstock, 1986; Johnson, 1986; Pikuła, 2013):

- On the individual level: biological conditions increasing the possibility of being a victim or an abuser, individual experience connected to abuse, eg. being abused in the childhood, mental disorders and illnesses, eg. schizophrenia, personality disorders, and/or somatic disorders like moving disability, drug addictions, etc. On the interpersonal level: the type of interpersonal relationships in the family, peer group, the risk of abuse behavior.

- On the demographic level: risk factors connected to the place of living, belonging to various social groups (school, neighborhood, place of work) with high level of unemployment, social mobility, population density, existence of deviant groups.

- On the socio-cultural level: socially approved attitudes concerning abuse, behavioral models, etc. (e.g. treating abuse as an indicator of courage, an efficient way of solving problems or situation control).

\footnotetext{
${ }^{1}$ In the theoretical part, the reference was made to research studies carried out in Canada and Israel, as well as to experiences in the field of education and work of social workers with older people experiencing violence, because in these countries mentioned areas of work and education of social workers are compiled in the best way, and research are conducted in most intensively way by well-prepared research teams.
} 
Joanna Matgorzata Eukasik, Norbert Gerard Pikuła, Katarzyna Agata Jagielska. The Preparation of Polish Social Workers to Work with Person Experiencing Domestic Violence.

Furthermore, the results of research conducted within the international EuROPEAN project (van Bavel et al., 2010) show that the notion of elder abuse is understood differently in different European Union countries. For example, according to the definition worked out in Ireland, abuse is an activity trespassing the fundamental rights of elders (Working Group on Elder Abuse, 2002). On the other hand the definition suggested in Holland stresses the meaning of the relationship between the victim and the abuser (Comijs, 1998). In other countries that phenomenon is understood first of all as home abuse (Czech Republic, Italy, Poland, Slovenia), abuse directed at the weaker including women, children and seniors (Czech Republic, Italy and Slovakia) and as discrimination (Slovakia). Such big disparity within understanding the notion "elder abuse" and the lack of a universal definition caused by that makes running comparative international studies of the phenomenon difficult (Jagielska et al., 2015, p. 280-281).

Even though since 2006 all theoretical approaches to abuse including home abuse in families, child abuse and partner abuse indicate elder abuse (assuming that each of those mentioned forms of abuse, i.e. physical, psychological, sexual, neglect or deprivation concern seniors as well) it is still the problem which has been relatively rarely mentioned in Poland. Even if it is mentioned it is undertaken by medical environment and marginalized by sociologists, teachers and educators, social workers, psychologists, police and law environment.

Elder abuse does not cause interest and is not perceived as an important threat for the old age. It is joined by unclear criteria of recognizing abuse and working out efficient procedures how to behave in case of encountering abuse and a low level of social awareness towards the problem which, subsequently, causes that an elder, being a victim of abuse, even while contacting a medical or aid institution not always can count on help and may be left alone (Kennedy, 2005). Difficulties in recognizing elder abuse come mainly from fear of false recognition, a low awareness of the abused people themselves, lack of knowledge on the appropriate procedure in case of abuse both on the side of the victims and professional workers of social and medical services.

To increase awareness of societies and professionals various EU countries conducted lots of actions and campaigns undertaking the problem of elder abuse and indicating support and help forms in the situations of suffering from abuse. However, there have been very few of them in Poland. One of those was the 2014 anti-abuse preventive campaign held in Wrocław including the elder abuse (http://www.kampaniaprzemoc.pl) and the project "Support Model" realized in it which aimed at creating Support Coordinators working with abused people in order to implement "The Change Program" in their situation (www.modelwsparcia.cis.wroclaw.pl). What is more, the research on the phenomenon of abuse and promulgating good practices for its prevention was conducted in the project "Unheard Voices: Developing the East Central European 
Network for the Prevention of Elder Abuse" financed by EASSW (Jagielska et al., 2015) and in the project EuROPEAN European Commission (van Bavel et al., 2010). The aim of the project was to define the frames for referring to elder abuse prevention all over Europe. Organizations from Austria, Czech Republic, Greece, Ireland, Italy, Holland, Poland, Slovenia and Slovakia took part in the project. In June 2010 a document "Elder abuse: background and place" was developed. The published work contained research results from nine countries which were to help understand the phenomenon of elder abuse. At the beginning of 2011 reports on particular social and cultural elder abuse environments were published together with a collection of 55 good practices in preventing abuse. A database of good practices on elder abuse prevention (van Bavel et al., 2010) containing materials translated into 9 languages was developed and it is intended to be disseminated among national and international policymakers, interested parties and experts. Among good practices there are no suggestions from Poland, which proves an occasional character of both elder abuse research and the preventive, prophylactic, intervention or therapeutic actions.

Elder abuse is a problem which still requires research and thorough studies allowing for defining the range of the phenomenon all around Poland. Despite the increase of interest in the issue of elder abuse there is still lack of national research, the subject of which concentrates on elder abuse and self-neglect. The research conducted so far have had local character (e.g. Halicka, 1995, 2010; Tobiasz-Adamczyk, 2009; Twardowska-Rajewska \& Rajewska-de Mezer, 2005; Rudnicka-Drożak, 2006; Sygit \& Ossowski, 2002; Synak, 2002, Bedyńska et al., 2009, Jaszczak-Kuźmińska \& Michalska, 2010; Korzeniowski \& Radkiewicz, 2015). However, that research gives only a partial view of the phenomenon and a variety of methods and research techniques used in them and even no compliance of definitions and forms of abuse (various authors presenting the research problem use various terminology and typologies) make it difficult to compare the research results from particular research centers.

Nevertheless the research implies a few urgent questions worth thorough research and undertaking actions connected to vocational education especially in relation to social workers, nurses, medical doctors and other professionals working with elders. Particularly, as it is shown, among other, in the research of Beata Tobiasz-Adamczyk (2009), people working with elders (TobiaszAdamczyk researched medical doctors, MOPS (City Center of Social Aid) employees, community and clinical nurses and DPS (Social Assistance Homes) employees have totally different images of the elder abuse phenomenon as a problem encountered in their jobs (as a social problem, the results in per cent are close for the researched people and much higher than those included in the experience of professionals), in the aspect of physical abuse (least differentiated data), mental abuse (most perceived by doctors, $30.4 \%$, least perceived by nurses, 
ca. $8 \%$, and social workers, $16 \%$ ), neglect ( $45.6 \%$ perceived by doctors and only $26.8 \%$ by social workers, $12.3 \%$ by community nurses and $10.9 \%$ by DPS employees), abandoning ( $20 \%$ by clinical nurses, $15.8 \%$ by doctors and considerably less by community nurses, MOPS and DPS employees), financial/material abuse ( $31.6 \%$ by doctors, $28.7 \%$ MOPS employees and nurses and DPS employees: 18.5-16.9\%). Considerable differences in the assessment of the phenomenon had a few reasons, one of which was shortage of profound knowledge on the phenomenon and intervention actions which should be undertaken in case of diagnosing abuse, lack of diagnostic tools and skills needed to use them. Those shortages decide upon the possibility of recognizing abuse (low recognizability) and undertaking intervention strategies (e.g. talking to a home community member, most often the abuser or a person dependent on such a person was treated as a way of responding to abuse by family at the victim's place of living).

Therefore there is a need of educating social workers on diagnosis, intervention and support of abused elders (cf. Tobiasz-Adamczyk, 2009).

\section{Challenges for social workers' education}

A social worker who is to work responsibly with elderly people, especially with those suffering abuse, must possess appropriate knowledge, skills and social competence. In Poland social workers get their work qualifications during university studies of both the 1st (bachelor) degree and the 2nd (master) degree at the courses of social work or pedagogy, sociology, family studies running qualification training courses within social work specialization.

A social worker can choose various specializations while studying. Among many of them (e.g. a family assistant, an institutional care assistant, social work with an elder and a handicapped person, a course on increasing activity and social guidance) the least chosen, unfortunately, are those giving a license to work with an elderly person (data come from the recruitment in 2012-2016 from the universities located in the southern Poland, which train social workers). The research encompassed university courses run at universities in southern Poland. The analysis of programs implies that those courses contain very little knowledge on diagnosis, intervention, support or appropriate forms of therapy referring to elder abuse. That knowledge is most often a part (e.g. 1or 2 hours) of a given subject which takes various needs and situations concerning elders into consideration (e.g. diagnosing needs of elders). Such small knowledge on the phenomenon in question incorporated in lots of other content, lack of skills in using appropriate diagnostic tools, conversation strategies, intervention or support activities and shortage of suitable therapy forms addressed at abused elders causes that even though in a situation when social workers suspect they may deal with 
elder abuse they do not undertake proper action because they possess neither skills nor knowledge on the subject. If such a situation does not change, social workers will still possess meagre knowledge and skills and present negative attitudes towards abuse like those proved by Tobiasz-Adamczyk (2009) in her work .

A well-trained social worker is the one who recognizes the appearance of symptoms of negative situations experienced by elders, reads them in reference to the needs of the people who she/he works with and undertakes suitable measures, i.e.:

- knows the needs of the elderly,

- can communicate efficiently and listen actively,

- can diagnose elder abuse and self-neglect,

- can undertake appropriate intervention strategies towards abuse victims and their abusers,

- knows forms of support for the abused,

- knows and can show forms of therapy and institutions running therapeutic activities for abused elders.

"While educating social workers one should pay special attention to issues dedicated to elders, and especially to recognizing life situation of seniors, proper recognition of their needs as it will enable suitable animation of the elders' lives" (Jagielska et al., 2016, p. 17).

\section{Conclusion}

The results of studies on elder abuse and the quality of education of social workers for the work in the area make it possible to assume that:

- Elder abuse exists in all forms but it is rarely or never perceived by social and medical workers (concerns home abuse, self-neglect and abuse suffered at aid institutions).

- Among institution employees abuse is marginalized and unnoticed. It is still a taboo. One can get too little knowledge and too few skills on the subject during university studies and there is little literature and discussion on the subject with a few forms of abuse e.g. sexual abuse or self-neglect existing in scientific discourse only marginally.

- The scale of the phenomenon is hard to assess: medical and social aid institutions employees, despite having the knowledge on diagnostic criteria, do not always undertake action in order to give help and support (there is no statistics or register of such activities).

- $\quad$ Lack of adequate knowledge of social workers on elder abuse, lack of standardized diagnostic tools for elder abuse assessment and of intervention procedures make the phenomenon marginalized. 
Joanna Małgorzata Łukasik, Norbert Gerard Pikuła, Katarzyna Agata Jagielska. The Preparation of Polish Social Workers to Work with Person Experiencing Domestic Violence.

Educational Experiences and Challenges

Therefore there is an immediate need to educate social workers on the work with the abused.

\section{References}

Band-Winterstein, T. (2015a). Health care provision for older persons: The interplay between ageism and elder neglect. Journal of Applied Gerontology, 34 (3), NP113-NP127. doi:10.1177/0733464812475308

Band-Winterstein, T. (2015b). Whose suffering is this? Narratives of adult children and parents in long-term abusive relationships. Journal of Family Violence, 30 (2), 123-133. doi:10.1007/s10896-014-9660-z.

Band-Winterstein, T., \& Eisikovits, Z. (2014). Intimate violence across the lifespan: Interpersonal, familial, and cross-generational perspectives. New York, NY: Springer.

Band-Winterstein, T., Eisikovits, Z., \& Lowenstein, A. (2006). Elder abuse and neglect in Israel - A Qualitative study (A Research Report). Haifa, Israel: The center for Research and Study of Aging, University of Haifa and Eshel. (In Hebrew).

Band-Winterstein, T., Smeloy, Y., \& Avieli, H. (2014). Shared reality of the abusive and the vulnerable: The experience of aging for parents living with abusive adult children coping with mental disorder. International Psychogeriatrics, 26 (11), 1917-1927. doi:10.1017/S1041610214001495.

Bedyńska, S., Brzezicka, A., Korzeniowski, K., Radkiewicz, P., \& Skarżyńska, K. (2009). Przemoc $w$ rodzinie wobec osób starszych i niepetnosprawnych, część I i II. Warszawa: Polska Akademia Nauk, Instytut Psychologii. Downloaded from: https:/www.mpips.gov.pl/gfx/mpips/userfiles/File/Przemoc\%20w\%20rodzinie/przemo c_spol.pdf and http://www.mpips.gov.pl/userfiles/File/Przemoc\%20w\%20rodzinie/ przemoc_prof.pdf

Comijs, H. C., Pot, A. M., Smit, J. H., Bouter, L. M., \& Jonker, C. (1998). Elder Abuse in the Community: Prevalence and Consequences, Journal of the American Geriatrics Society, 7 (46), 885-888.

Freeman, M. (ed.). (2008). Domestic Violence. Aldershot, UK: Ashgate.

Halicka, M. (1995). Elder Abuse and Neglect in Poland. Journal Elder Abuse and Neglect, 6 (3-4), 157- 169.

Halicka, M., \& Halicki, J. (2010). (ed.). Przemoc wobec ludzi starych. Na przykładzie badań środowiskowych w województwie podlaskim. Białystok: Wydawnictwo Temida 2.

Hwalek, M. A., \& Sengstock, M. C. (1986). Assesing the Probability of Abuse of the Eldery: Toward Development of a Clinical Screening Instrument, The Journal of Applied Gerontology, 5 (2), 153-173.

Jagielska, K., Łukasik, J. M., \& Pikuła, N. G. (2015). Violence against the elderly. ChallengesResearch-Action. Toronto: NovaPrinting.

Jagielska, K., Pikuła, N. G., Łukasik, J. M., \& Kasprzak, M. (2016). Social workers' education in the context of the challenges of the ageing society, Edukacja Ustawiczna Dorostych, 1 (92), 7-17.

James, R. K., \& Gulliland, B. E. (2013). Crisis Intervention Strategies. Brooks/Cole, Belmont, Canada.

Jaszczak-Kuźmińska, D., \& Michalska, K. (2010). Przemoc w rodzinie wobec osób starszych $i$ niepetnosprawnych. Poradnik dla pracowników pierwszego kontaktu. Warszawa: 
Ministerstwo Pracy i Polityki Społecznej. Downloaded from: http://ms.gov.pl/Data/ Files/_public/ppwr/poradnik.pdf

Johnson, T. (1986). Clinical issues in the definitione of elder mistreatment. In: K.A. Pillemer, R.S. Wolf (ed.). Elder Abuse: Conflict in the Family (pp. 167-196). MA: Auburn House, Dover.

Kennedy, R. D. (2005). Elder Abuse and Neglect: The Experience, Knowledge, and Attitudes of Primary Care Physicians, Family Medicine, 37, 484-485.

Korzeniowski, K., \& Radkiewicz, P. (2015). Przemoc $w$ rodzinie wobec osób starszych $i$ niepetnosprawnych. Raport $z$ badania ogólnopolskiego 2015 r. oraz badania porównawczego $z$ lat 2009-2015. Warszawa: Polska Akademia Nauk, Instytut Psychologii. Downloaded from: https://www.mpips.gov.pl/gfx/mpips/userfiles/_public/ 1_NOWA $\% 20$ STRONA/Przemoc\%20w\%20rodzinie/Przemoc\%20w\%20rodzinie $\% 20$ n owe/2015/Przemoc_wobec_starszych_2015.pdf

Krzyszkowski, J. (2013). Pomoc społeczna wobec starzenia się społeczeństwa polskiego. Przeglad Socjologiczny, 2 (62), 9-31.

Lachs, M. S., \& Pillemer, K. A. (2004). Elder abuse. The Lancet, 364 (9441), 1263-1272.

Lowenstein, A. (1995). Elder Abuse in a Forming Society: Izrael. Journal of Elder Abuse \& Neglect, 6 (3-4), 81-100.

Nerenberg, L. (2006). Communities respond to elder abuse. Journal of Gerontological Social Work, $46(3 / 4), 5-33$.

Pikuła, N. (2013). Senior w przestrzeni społecznej. Warszawa: Wydawnictwo BORGIS.

Working Group on Elder Abuse (2002). Protecting Our Future. Dublin: Stationery Office.

Rudnicka-Drożak, E. (2006). Zjawisko przemocy wobec osób starszych jako forma zagrożenia zdrowia. Konstrukcja narzędzia badawczego dla potrzeb podstawowej opieki zdrowotnej. Lublin: Akademia Medyczna im. prof. Feliksa Skubiszewskiego.

Sygit, E., \& Ossowski, R. (2002). Przemoc wobec osób starszych ze względu na ich wiek, płeć i wykształcenie. Gerontologia Polska, 16 (3), 163-168.

The Toronto Declaration on the Global Prevention of Elder Abuse. (2002). Toronto - Geneva: World Health Organization (WHO). Downloaded from: http://www.who.int/ ageing/projects/elder_abuse/alc_toronto_declaration_en.pdf

Tobiasz-Adamczyk, B. (ed.). (2009). Przemoc wobec osób starszych. Kraków: Wydawnictwo Uniwersytetu Jagiellońskiego.

Twardowska-Rajewska, J., \& Rajewska-de Mezer, J. (2005). Nadużycia wobec seniorów w ich rodzinach. In: M. Bińczycka-Anholcer (ed.). Przemoc i agresja jako problem zdrowia publicznego (pp. 446-458). Warszawa: Polskie Towarzystwo Higieny Psychicznej.

Van Bavel, M., Janssens, M., Schakenraad, W., \& Thurlings, N. (2010). Elder Abuse in Europe Background and Position Paper. EuROPEAN project. Downloaded from: http://www.ouderenmisbehandeling.be/VLOCO/Files/Elder\%20Abuse\%20in\%20Europ e.pdf

Krug, E. G., Dahlberg, L. L., Mercy, J. A., Zwi, A. B., \& Lozano, R. (eds). (2002). World report on violence and health. Geneva, Switzerland: World Health Organization (WHO). Downloaded from: http://apps.who.int/iris/bitstream/10665/42495/1/9241545615_ eng.pdf

\section{Websites:}

www.modelwsparcia.cis.wroclaw.pl.

www.kampaniaprzemoc.pl 